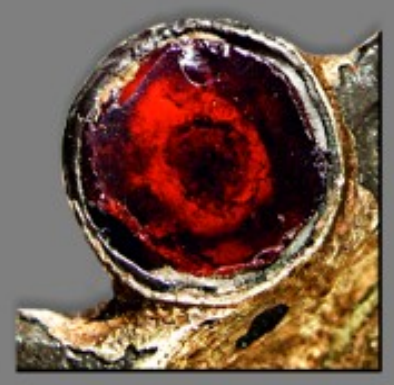

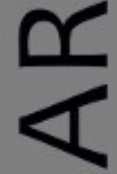

$\sim$

ш
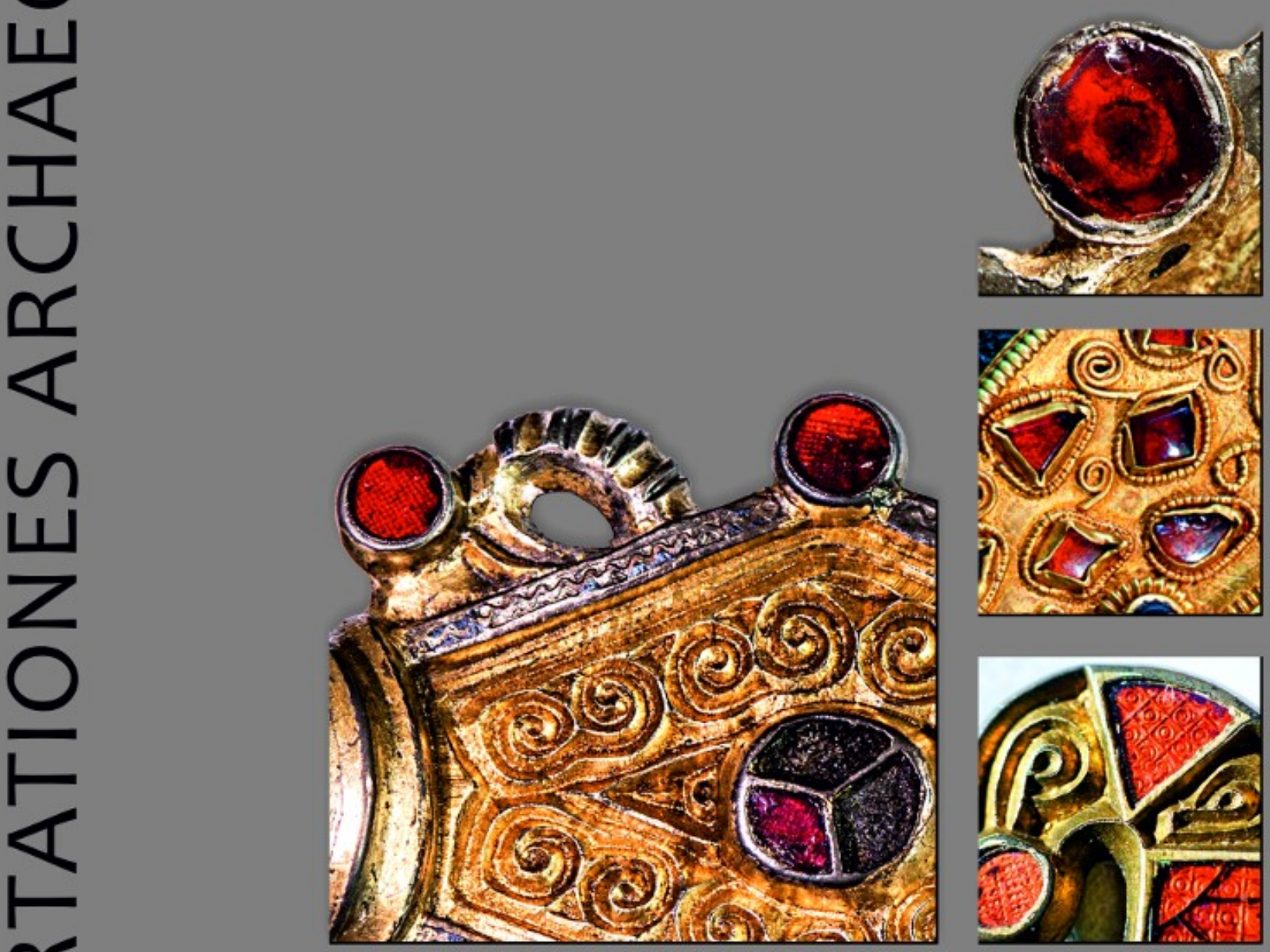

E

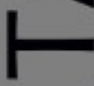

œ

山

n

ก

$\overline{0}$
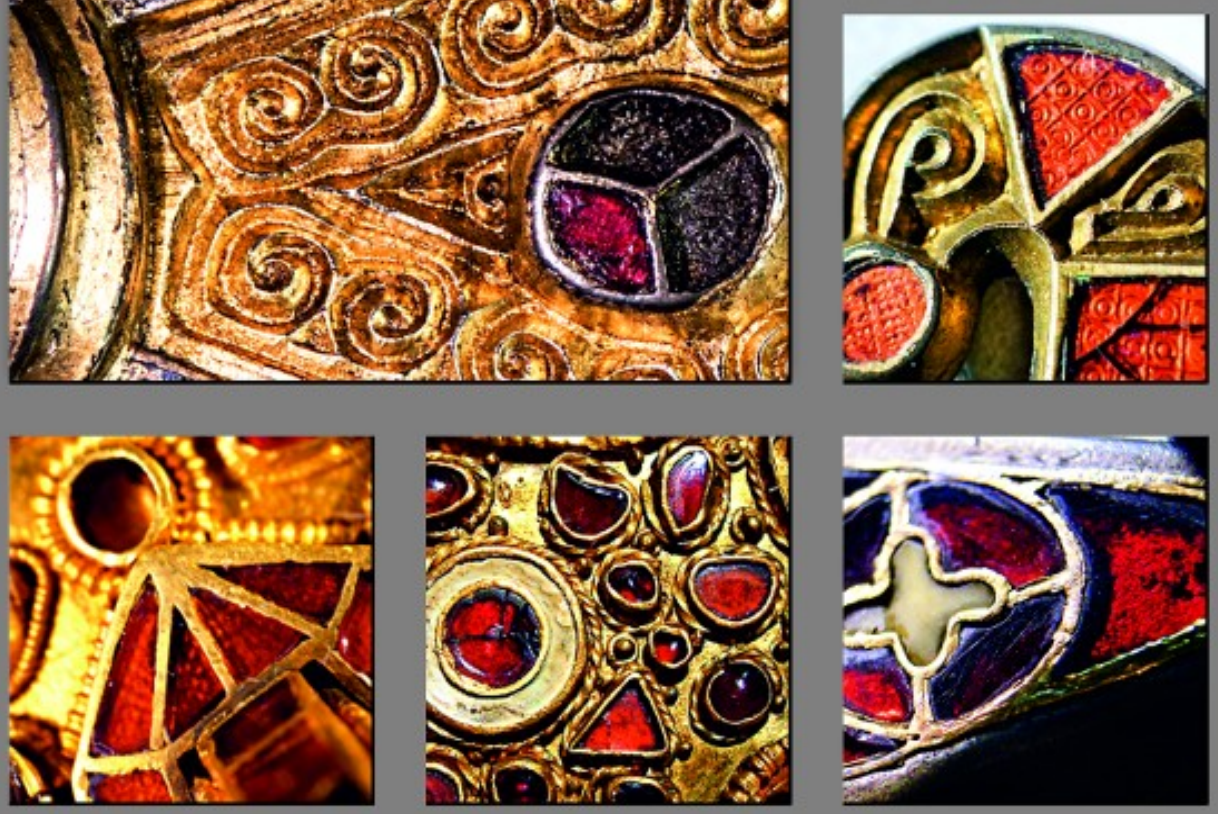

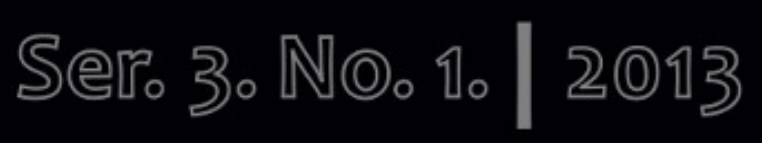




\section{Dissertationes Archaeologicae ex Instituto Archaeologico}

Universitatis de Rolando Eötvös nominatae Ser. 3. No. 1.

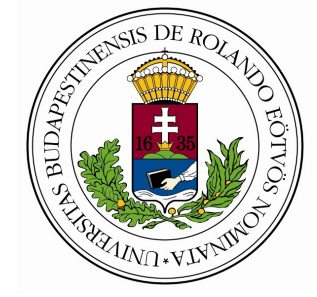

Budapest 2013 
Dissertationes Archaeologicae ex Instituto Archaeologico

Universitatis de Rolando Eötvös nominatae

Ser. 3. No. 1.

Editor-in-chief:

DÁvid BARTUS

Editorial board:

LÁSZLÓ BARTOSIEWICZ

LÁSZLÓ BORHY

ISTVÁN FELD

GÁBOR KALLA

PÁL RACZKY

Miklós SzABÓ

TIVADAR VIDA

Technical editors:

DÁvid BARTuS

GÁBOR VÁCZI

ANDRÁs BöDŐcs

Proofreading:

Zsófia KondÉ

SzILvia SzÖLlősI

Available online at http://dissarch.elte.hu

Contact: dissarch@btk.elte.hu

\section{$\underline{\text { PKP }}$ \\ PUBLIC \\ KNOWLEDGE \\ PROJECT}

(C) Eötvös Loránd University, Institute of Archaeological Sciences

Budapest 2013 


\section{Contents}

\section{Articles}

Melinda TORBÁGYI - István VIDA

The coin hoard of Abasár

Anikó BózsA

21

Roman mirrors from a private collection in the Hungarian National Museum

Lajos JuHÁsz

45

The Biesheim cameo - a reinterpretation

\section{Methods}

Péter CsIPpÁN

$A z$ állatcsont, mint információhordozó leletanyag

Kata DÉvAI

Terminológiai alapfogalmak régészeti korú üvegtárgyak elemzéséhez

Lőrinc TimáR - Zoltán Czajlik - Sándor Puszta - Balázs Holl

$3 D$ reconstructions using GPR data at the Mont Beuvray

\section{FIELD REPORTS}

Zsolt MESTER

Excavation at a new Upper Palaeolithic site of the Eger region (Northern Hungary)

László BORHY - Dávid BARTus - Emese SzÁmadó

Short report on the excavations at Brigetio (Szőny-Vásártér) in 2013

Dénes HulLÁm - Zsófia RÁcz

Report on the participation of the Eötvös Loránd University at the Wielbark Archaeological Field School in Malbork-Wielbark, Poland

Gábor VÁczi - Dávid BARTus

Short report on the excavations at the site Makó - Igási Ugar

Maxim MoRdovin

Short report on the excavations in 2013 of the Department of Hungarian Medieval and Early Modern Archaeology (Eötvös Loránd University, Budapest)

\section{THESIS ABSTRACTS}

Kitti KÖHLER

Biological reconstruction of the Late Neolithic Lengyel Culture 
Cultural connections and interactions of Eastern Transdanubia during the Urnfield period

Orsolya LÁNG

Urban problems in the civil town of Aquincum: the so-called „northern band”

Nikoletta SEY

Questions of bronze workshops in Roman Pannonia

Kata DÉvaI

Glass vessels from Late Roman times found in graves in the Hungarian part of Pannonia

Eszter HORvÁTH

Gemstone and glass inlaid fine metalwork from the Carpathian Basin:

the Hunnic and Early Merovingian Periods

Gergely SzEnTHE

Vegetal ornaments in the Late Avar decorative art

Péter LANGó

Relations between the Carpathian Basin and South East Europe during the 10th century.

The evidence of the minor objects

Ciprián HoRvÁTH

The Cemeteries and Grave Finds of Györ and Moson Counties from the Time

of the Hungarian Conquest and the Early Árpádian Age

András Sófalvi

The border- and self-defence of Szeklers from the Medieval Age till the Age of Principality.

Castles and other defence objects in the settlement history of Udvarhelyszék 


\title{
Questions of bronze workshops in Roman Pannonia
}

\author{
Nikoletta Sey \\ Institute of Archaeological Sciences \\ Eötvös Loránd University \\ seyniki@gmail.com
}

\begin{abstract}
PhD thesis submitted in 2013 to the Archaeology Doctoral Programme, Doctoral School of History, Eötvös Loránd University, Budapest under the supervision of László Borhy.
\end{abstract}

\begin{abstract}
Aims of the dissertation
The aim of the dissertation, beside collecting the evidences of bronze working in Pannonia is to investigate the activity of bronze workshops in the Roman era as detailed as possible. Since bronze was used in the production of most of the objects of everyday use, it is important to deal with the questions of production as well as the economic background. However, the examination of bronze working cannot be fully separated from that of other metal working and economic activities. For example other lead and iron processing workshops can provide valuable pieces of information. In many cases these workshops operated together, forming an industrial area with other economic units in certain types of settlements (Fig. 1). In the dissertation, based on these observations and the evaluation of artefacts related to bronze working in Pannonia, I tried to give a view as comprehensive as possible about the activity of bronze workers. The different tools and the technical specialties observed in the workshops can give an insight into the local customs and methods of bronze working.
\end{abstract}

Assembling a catalogue of the artefacts from Pannonia is an essential aim of the dissertation, as several new objects related to bronze working came to light since previous publications based on earlier excavations have been published. Although a significant part of the objects are stray finds, they should not be left out of consideration when creating a comprehensive view. While making the dissertation it became obvious that certain objects already perished or are inaccessible therefore in some cases it was necessary to rely on earlier publications. Possible shortcomings of the data collection could derive from the fact that certain objects are stored with wrong definitions as their function has not been recognized correctly, thus they could not be investigated. Despite all these complicating circumstances, the catalogue contains a large number of artefacts.

The comparison between the local finds and those known from other provinces clearly shows the regional similarities and differences. In the case of bronze workshops, the type and size of the settlement should not be left out of consideration during the evaluation.

One of the most important aims of the dissertation is to answer the questions of production techniques and to reconsider the earlier terminology, as well as to investigate the activity of the workshops by setting the methods applied in Pannonia against those used in other provinces. Thus, the discussion of the questions of bronze workshops in Pannonia is based on the gathered artefacts, the earlier publications, and the overview of the related research in other provinces. 


\section{Method and structure of the dissertation}

The first chapter of the dissertation is the Introduction, divided into two subsections: the first contains the aims and the general introduction (1.1), while the second part is a summary of previous research on bronze working in Pannonia and other provinces as well as other metallurgical research (1.2).

The second chapter analyses the antecedents of roman bronze working along with the depictions and written sources (2). Certain tools could be used for several activities, which further complicates their identification based on pictures. Written sources may provide valuable pieces of information about the contemporary bronze working customs and the attitude of people towards bronze workers and their profession. These documentations might be prejudiced of course, thus they should be handled with reservations. Based on the sources one can get an insight into how bronze workers and their products were estimated by the contemporaries.

An important part of the dissertation is the third chapter, where I examined the raw materials and the questions of production techniques. In the first subsection of the chapter the significance of the inspection of raw materials and composition is discussed (3.1), while the second subsection deals with the questions of production techniques (3.2) based on the different experimental archaeological methods as well as the traces perceptible on the excavated finds. Accordingly, among the production techniques founding and sheet-working processes could be separated. Despite the fact that a significant part of the related finds in Pannonia are stray finds and the above-mentioned difficulties of their identification, the traces of several production processes could be observed during their inspection. At the founding techniques it can be clearly seen what kind of processes were in use in Pannonia. Examining these methods, some of them can be paralleled with the ones originating from other provinces, but some of them lack proof in local destinations. The regional differences may be caused by the variance of demand in quantity and quality. Also in the case of sheetworking there is plenty of information about the various reparation and production techniques, based on the artefacts from Pannonia.

The most important chapter of the dissertation is the list of the sites in Pannonia where objects related to bronze working were found as these refer to bronze workshops (4). The list includes all data and details related to metal working in the province known to us. In the description of each site the newly excavated artefacts are introduced together with those known from earlier publications. The examination of those settlements in Pannonia where objects related to bronze working were found shows that this activity existed in some form at any type of settlement. This is logical since the major part of everyday tools and objects were made of bronze. Considering that only a minor part of the evidences of bronze working survived, it can be assumed that many more settlements had bronze workshops. Of course this is only an assumption without proof, but after the examination of the sites it is evident that the bronze workshops in Pannonia developed depending on the type, size and demand of a certain settlement.

In the next chapter the structure and operation of the bronze workshops is introduced based on the excavated sites and the international archaeological literature (5). Within the chapter the analysis and specification of the exact functions of different types of smelters (5.1.1), the 
crafting tools (5.1.2) and the casting models and negatives (5.1.3) are discussed. It is evident from the artefacts that not all the tools can be reconstructed based on the excavated sites; in certain cases the ethnographic parallels of the production techniques must be invoked. It is often difficult to define the full equipment of a workshop. Based on the survey of the artefacts, the workshops could have functioned with the range of tools mentioned in the chapter. The tools and objects might vary from workshop to workshop, but basically they were developed to the same pattern.

The next aspect of the examination of workshops is the possibility of specialization, discussed in the next chapter (5.2). One aspect of the distinction between workshops is the specialization on the production of certain objects (5.2.1) eg. military equipment (5.2.1.1), brooches (5.2.1.2), sculpture (5.2.1.3), pots (5.2.1.4) or enamel-decorated objects (5.2.1.5). Another aspect is the technique applied in a certain workshop (5.2.2): from a technical point of view three categories can be separated, the workshops specialized on sheet-working (5.2.2.1), casting (5.2.2.2) and repairing (5.2.2.3).

In the case of specialized workshops, no regularity can be observed neither in the period, size, location, nor in the settlement type. Most probably the specialization of workshops was influenced by the changing demands of the area in the different eras which affected the objects manufactured as well as the production techniques. The distinction of the workshops based on the crafting techniques comes from the different production methods of certain objects and tools, and the specific demand for these in a certain period. In the first centuries of the Empire the supply of raw materials was probably untroubled, while in the 3rd and 4th centuries AD the significance of recycling and repairs grew due to the decline of commerce. Though workshops dealt with repairs in earlier eras as well, the method became popular in the late Roman age beside sheet-working which demanded less raw material.

The next chapter discusses the questions of the serial production of objects (5.3) as well as the difficulties of the identification of local bronze workers and of objects and tools found in Pannonia that were marked by an artisan (5.4). In the case of the unmarked objects or tools and especially objects of minor art, these can occasionally be attributed to workshops or bronze workers stylistically. Although in many cases this is not possible, it should not be left out of consideration.

\section{Major achievments of the dissertation}

In the chapter of crafting techniques, the process of the preparation of bronze itself is necessary to be introduced first.

The first step is the extraction of copper from the ore, which takes place in a furnace, and can last 5-20 hours while the rock and the slag is removed. After the extraction of the copper a distinction must be made between the preparation processes of brass and bronze. Brass is made by so-called cementation, where the zinc vapored from zinc ore diffuses with copper. In the case of the preparation of bronze, copper was put into a closed pot with calamine and charcoal, and was heated at $1000{ }^{\circ} \mathrm{C}$ for 2 hours. The heating is very important in this process, since zinc turns into gas at $918{ }^{\circ} \mathrm{C}$ while clean copper melts at $1083{ }^{\circ} \mathrm{C}$, which temperature must not be reached before the zinc combines with the metal. Later the temperature rises and the alloy becomes unitary, the bronze will contain about $30 \%$ of zinc. 
One method of melting metals is when mineral copper $(\mathrm{Cu} 2 \mathrm{O})$ and charcoal $(\mathrm{CO})$ are heated to about $1100{ }^{\circ} \mathrm{C}$ in a pot, as a result copper $(\mathrm{Cu})$ and carbon-dioxide $(\mathrm{CO} 2)$ are won.

Several methods of bronze elaboration are known from the Roman age. In the case of casting techniques, the so-called lost wax process was practiced in the antiquity. At the casting processes, a distinction must be made between the preparations of large-sized sculptures and small-sized articles of personal use. In antiquity larger statues were made by jointing the separately casted smaller parts together. No data is available on the production of largesized statues from Pannonia, while the proofs of the production of small-sized sculptures and personal articles have been revealed at several settlements in Pannonia.

The necessary temperature for casting was reached by heating the charcoal in the furnace with a windbag. At the adequate temperature the metal was put into the pot in smaller doses and at equal time intervals in order to prevent overheating and hydrogen gas to be left in the alloy. At the smelting of copper the added iron enables the oxidation and helps the clotting of slug, making it easily removable through the upper, open part of the pot. With this technique the iron content can be reduced below $0,5 \%$, which was enough to allow the cold and hot working of the metal.

After the casting, certain reworks were necessary to be done on the objects. The smaller seams were corrected by rasp and emery, and leather and granulated materials were used for polishing. The smaller failures, bubbles and flashes were not corrected in every case, only when a work of high standard was required. In these cases a tetragonal cutting on the surface of the object was made, especially on sculptures, and a bronze annex was hammered into it, or sometimes worked into the cutting after being heated. At subsequent correctional processes these annexes were connected to the statue by studs, or in certain cases with glues of animal or vegetal origin.

The lost wax casting technique required special facilities in the workshops. Although furnaces were revealed only in a very few cases at the excavations in Pannonia, a great number of used and unused casting pots were found at the sites. Furthermore, half-finished and refuse casts as well as casting models also allude to casting activity of this area. During the investigation of the artefacts, several observations were made related to the questions of production techniques. In connection to the artefacts specified as casting models the question emerges whether any bronze was ever casted into these as many of these clay negatives do not carry any sign of heating. The experimental archaeological methods also prove that the dried negatives were pre-heated to $150{ }^{\circ} \mathrm{C}$ before the hot metal of $1080-1150{ }^{\circ} \mathrm{C}$ was casted into them. The lack of signs of heating on these negatives supports the hypothesis that it was the wax model of the object that was formed this way. A cast from Brigetio also supports this hypotyesis, as it is clearly visible that the covering clay was not removed from the brooch. This piece is a good example of how the brooch was made by casting the bronze into the clay form, which was previously created by building the clay around the wax model that was formed in the original negative. Another proof of this technique is an artefact from Szőny-Vásártér, where also the clay covering was not totally removed from the cast. The seams on the sides of the objects refer to the existence of the casting technique where more casting models were used to make a single cast. Based on this evidence both techniques might have been in use. Although unfortunately the negative and positive parts of a casting 
model were never found together in Pannonia, examples ar known from other provinces. Because of this technical problem, the negatives that cannot be proved to be used at casting are discussed as auxiliary negatives in the dissertation, since this is less misleading in the terminology of production techniques. Among the collected artefacts of Pannonia the lead models are represented as well, which were used later as models for the objects made of bronze.

The collection of Roman age bronze workshops in Pannonia raises several difficulties. At certain sites, the artefacts which would unambiguously refer to workshops often occur as stray finds or single objects. Although these finds prove the existence of workshops, the exact location and function of these cannot be determined. There are only a few artefacts from Pannonia in the museums which were found in the context of a workshop. However, the artefacts as well as the half-finished and refuse casts that are undoubtedly of local origin give an insight into the metal working habits and methods of the province.

In the dissertation, the workshops discovered at certain sites are collected, considering the artefacts to be found in museums presently as well as the results and hypotheses of earlier researchers. It is important to mention that the cause of incidental shortcomings may be the destruction and inaccessibility of certain artifacts, and also some data seem unrealistic after the reconsideration of earlier researches using the up-to-date research methods.

Apropos of the Roman age bronze working general economic questions emerge, for example whether the self-sufficiency or the use of goods arriving from different production centres was the main source of supply in certain areas. Commerce (particularly the overland trade) made various goods considerably more expensive, thus it is obvious that beside luxury goods which were expensive anyway, everyday goods used by the common people had to be manufactured locally. Therefore signs of some kind of bronze working turn up widely in Pannonia. Apropos of the evaluation of these signs, new questions emerge when dealing with the artefacts of other provinces.

One of the difficulties of the research of metal working is that archaeological finds that undoubtedly prove bronze working rarely turn up in Roman settlements. The reason for this is that the unfinished, waste and disused samples were re-smelted; therefore they were preserved only in exceptional cases. Also the clay casting moulds perished due to the quality of the soil, therefore it is difficult to size up the bronze working of a certain area. However, it is evident that some form of bronze processing should have existed even in the smaller settlements. This has several obvious reasons. On the one hand, the necessity of raw material is not bound to an area as by re-smelting the disused bronze objects workshops could have existed anywhere. On the other hand, it does not need a significant space, nor tools or devices, and furthermore it is an advantage if the goods are crafted locally and can adapt to the demand and taste of the customers.

Within the same settlement workshops with different facilities and producing different types of goods might have existed in the different periods. If the workshops are well documented, their location can provide important data. Further on it is also evident that against the common method bronze workshops settled not only outside the city wall, but inside as well, thus no common convention in the localization can be observed. Another question is raised in connection with the scale of production, as workshops can be categorized accord- 
ing to their size, for example the small-sized 'family' workshops, or the ones consisting of more rooms, functioning with one or two employees, as well as the larger ones employing several workers and practicing division of labour. The investigation of these workshops in Pannonia is quite difficult because of the shortcomings of the research in this field and the inaccurate documentation of earlier excavations, but on the basis of examples observed in other provinces data can be inserted into these models.

The economic form of metal processing can be observed according to several principles, laid down among others by B. Gralfs. According to these it is important to consider certain factors during the investigation of workshops in certain areas. For example the localization of the workshop can be a factor: whether it was located in a rural settlement, a town, a villa or a military camp or fortress. It is obvious that depending on the type of settlement, different demand emerged for quality and quantity. Another question to be answered within this issue is whether the workshop was located in an industrial area, or separately, maybe as a member of a group of other workshops. Such structural examination is only possible in the case of excavated workshops, while most of the stray finds related to bronze workshops give no hint about it. Several possibilities emerge on geographical basis too, since metal process ing workshops are known in the central part of provinces, close to road-systems, at larger crossings and in the vicinity of raw material sites. Finally a further differentiation is possible and necessary on the basis of the size of the workshops and the type of goods produced. A complex survey considering all these aspects can give a more complete view of bronze working. The context of research in Pannonia requires in many cases the information from the more thoroughly researched provinces to be used as a basis of comparison to during the examination of local material.

Therefore, the appearance of new excavation methods, the spread of material analyses and the re-evaluation of previously excavated finds made the a completion of a comprehensive dissertation necessary. In most cases, the localization of the workshops is impossible at the sites in Pannonia, since only one or two objects refer to the existence of the workshop that functioned there. However the unfinished or waste objects, the moulding casts, the auxiliary negatives, the moulding pots and the unsmelted metal stocks prove the existence of local bronze working. The exact localization of the workshop is possible only if the furnace was excavated as well, however, it is only the smelting-furnaces which can be considered as obvious proofs of metal processing. Of course, on the basis of the find context, other furnace types can also be connected to metal working.

Discussing the questions of bronze workshops, it is obvious, that the topic can and should be examined from several aspects. One of these is by all means the operation, localization and structure of the workshop in a certain settlement. Furthermore, it is necessary to examine the various settlement types separately. The bronze workshops in towns, military camps, military towns, vici and villas might have been different in size, facilities as well as expertise. Observing these factors, the different demands of certain settlement types are revealed as well. Finds related to workshops are known from each settlement type in Pannonia, though not to an outstanding extent. Their significance is great since only a few excavated workshops exist in Hungary.

Because of the relatively small number of revealed artefacts the overall picture is quite in- 
complete. But the necessity of some form of bronze working to everyday life allows the conclusion that such an activity existed in most parts of the populated areas. Depending on the size and significance of the settlement, after satisfying local demand, the workshops could have produced goods for export as well. Also the existence of travelling artisans must be taken into consideration to a certain extent.

One of the main achievements of the research is that by examining the different settlement types, it can be stated that both craftsmen supplying soldiers and those supplying the civil population existed. That is why a part of workshops specialized on certain goods or techniques. The specialization on different goods as well as the usage of different techniques was caused by the growth in demand in certain periods. The specialization to reparation is the most clearly distinguishable as in the Late Roman Period the necessity of reparation of different goods came to the front because of the regression of production. While before repairs comprised only a minor activity for the craftsmen, in the Late Roman Period some workshops specialized on this express purpose. Of course it is difficult to prove the truth of this statement, but the tendency drawn by the artefacts from different periods points to this direction.

Examining the bronze workshops, it becomes evident that they cannot be regarded separately from other workshops. In most cases a complex examination of bronze working and other industrial activities is reasonable. Bronze working must primarily be analysed together with other metal workshops, namely with smithies and plumber workshops. As it is noticeable at several sites, these workshops were not separated, but functioned in the same building, possibly even under the control of the same craftsman. This hypothesis seems logical regarding the fact that all three branches of metal processing used the same raw materials, tools and technical knowledge. Functionally, bronze casting was not an everyday activity therefore the craftsman could perform other metal processing activities between the castings.

Another achievement of the dissertation is the exact definition of the tools and other devices used at the production of bronze which came up during the collection and evaluation of the artefacts related to workshops and the review of the eventual terminological problems. For this, the adaption of the results of recent research and the various experimental archaeological methods as well as the consideration of ethnographic parallels are indispensable.

Thus the dissertation aims at gathering all information about Roman bronze workshops in Pannonia by collecting the artefacts from earlier excavations and private collections as well as considering the results of recent excavations. According to these evidences, bronze working in Pannonia evidently fits into the image drawn on the basis of related artefacts from other provinces. 


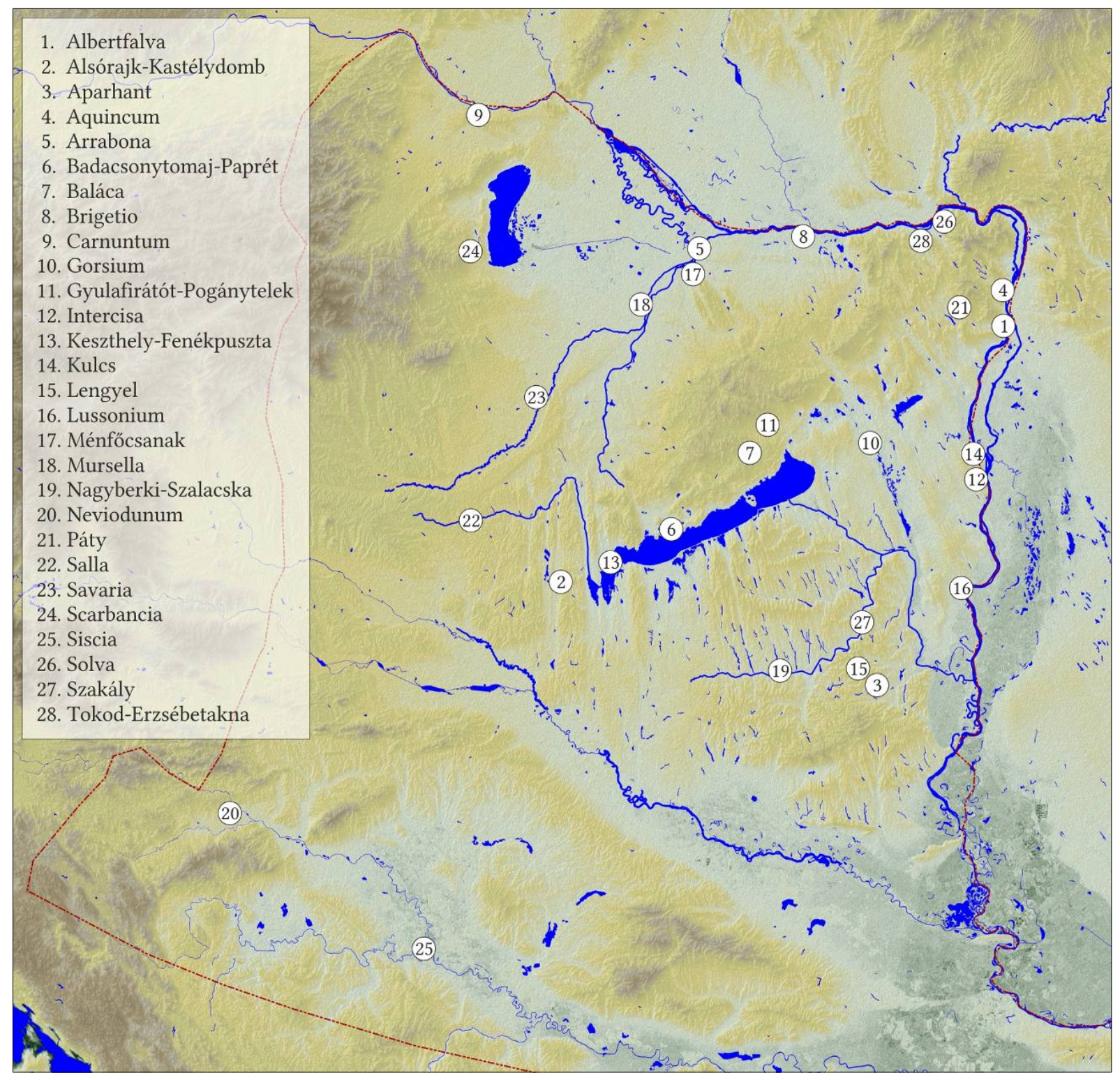

Fig. 1. Bronze workshops in Roman Pannonia. 